\title{
The 1991 State and Local Fiscal Crisis
}

Every DECADE or so the state and local government sector begins to behave strangely. Either the aggregate budget surplus gets very high, as it did on three occasions in the 1970s and 1980s, or very low, as it has recently. Although a low aggregate budget surplus is not the worst of national tragedies, it can be the harbinger of other problems and the cause of painful budget cuts and tax increases. And for those worried about low national saving rates, a low or falling state and local budget surplus is another nail in the coffin.

There is no dearth of potential explanations for the recent drop in the surplus. State and local politicians themselves have been quick to blame forces beyond their control-the recession, changes in federal grant policies (which were the main explanations for earlier budgetary swings), or federal mandates that states pick up new costs under medicaid and other federal programs. By contrast, economists who have looked at the present situation conclude that states and localities have caused their own problems. Stephen Moore has emphasized the rapid growth in state spending, and Steven Gold has pointed to states' unwillingness to raise taxes. ${ }^{1}$

One goal of this paper is to answer some of these factual questionsWhat has caused the drop in the surplus? What role was played by external factors and by states' and localities' own policies? How damaging is the drop? I try to answer these questions with some simulations from a

I have benefited from the comments of Paul Courant, Steve Gold, Robert Gordon, Jeff MacKie-Mason, Robert Reischauer, Charles Schultze, Ralph Smith, and Bruce Vavrichek.

1. Moore (1991) and Gold (1991). 
time series model fit to annual data over the $1955-90$ period. I then turn to some normative considerations-What is the optimal behavior for state and local budgets over the business cycle? And what, if any, policy changes should be taken to deal with the present problem?

\section{How to Think about Budgets}

Readers of the 1991 financial press must have been surprised to learn about state and local budget deficits. It seems like only yesterday when the large budget surpluses of state and local governments were being used as an argument for not worrying about large federal budget deficits.

Things have changed in the past few years, but perhaps not as much as these statements suggest. Most newspaper commentary is based on prospective operating deficits for selected state or local governments. Because newspapers tend to report the worst deficits, these deficits for selected governments do not represent fiscal conditions for the state and local sector as a whole. Furthermore, prospective deficits are usually larger than actual deficits because they trigger budget restrictions. On balance, other definitions of the deficit may be better measures of fiscal position.

\section{Measures of the Surplus}

The most common aggregate measure of state and local fiscal conditions is the state and local budget surplus reported in the national income accounts (NIA). This series, expressed as a percent of GNP, is shown in figure 1 for the 1955-90 period. In recent years, the series does show grounds for moderate concern. Back in the 1950s it was actually negative-the overall state and local sector was in deficit-but a strong upward trend began in 1958 and continued through 1984, interrupted only by a few high unemployment years (shown as vertical lines in the figure). In 1984, the high state and local surplus was being used as an argument for not worrying about federal deficits. But no sooner had these arguments been made than the NIA state and local surplus began diving, from 1.7 percent of GNP to 0.6 percent of GNP by 1990 .

There could be two reasons for paying attention to the NIA budget surplus-it describes the fiscal position of the sector in question, and it 
Figure 1. Measures of State and Local Government Surplus, 1955-90

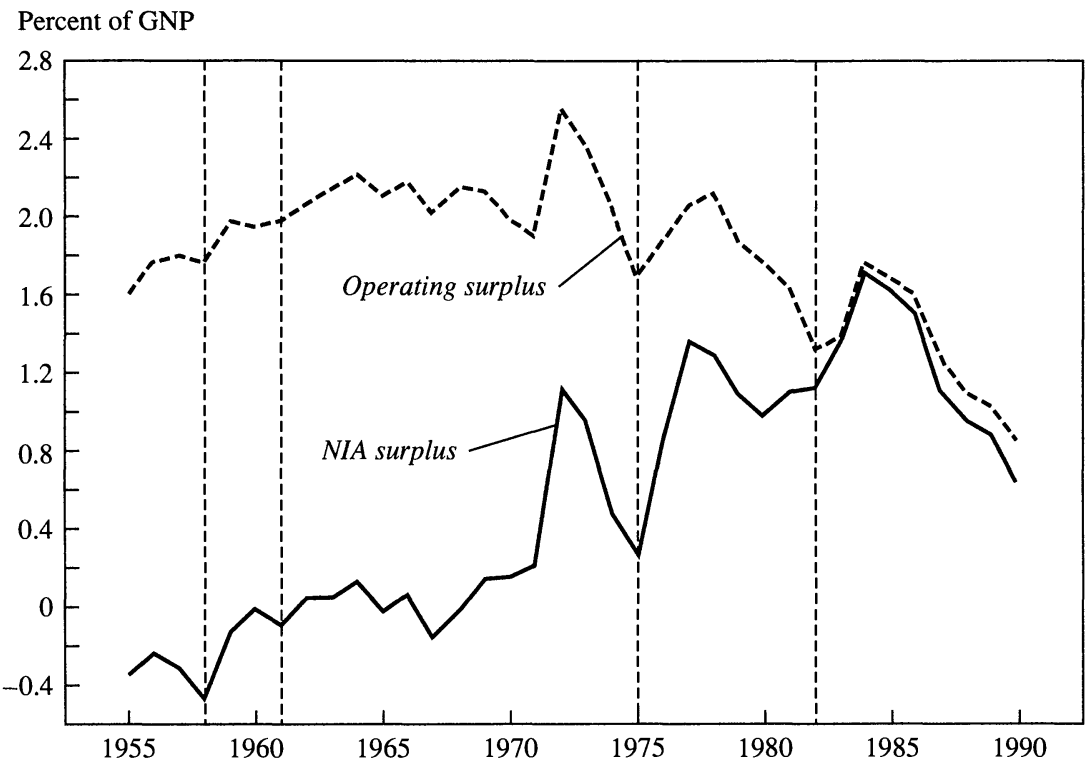

Source: National income accounts (NIA), annual data. The operating surplus is defined as the NIA surplus minus the pension surplus and construction spending. The vertical lines mark years of high unemployment.

describes the contribution of the sector to overall national saving and investment. For state and local governments, however, an alternative definition of the state and local surplus is better on both counts. This alternative series, called the operating surplus, excludes two important items:

-The cash surplus of pension funds for state and local employees. For budget analysis, this cash surplus should be excluded because it is generally not under the control of state and local officials; firm rules usually dictate how much is contributed to government employees' pension funds. For national saving and investment analysis, the NIA treats the cash surpluses of private pension funds as personal saving because they are earmarked for the contributing employees. Thus, if one is trying to measure the contribution of state and local governments to national saving, it makes sense to apply consistent treatment here, which means excluding these cash pension surpluses from the state and local surplus. ${ }^{2}$

2. Moreover, the cash surplus is not even a good measure of the change in financial health of the pension funds. The actuarial surplus would be a better measure. 
- State and local construction spending. For budget analysis, states and localities generally use a form of capital budgeting under which they can finance their capital expenditures by bonds, with the interest on the bonds paid over time as the capital is depreciated. The NIA has no precise measure of state and local capital spending, but construction spending comes reasonably close. A surplus measure that excludes construction spending gets closer to the budget variable that actually drives state and local fiscal behavior. ${ }^{3}$ For national saving and investment analysis, it is often argued that overall saving-investment statistics are defective, because, among other things, they ignore the public investment done by state and local governments. Excluding construction from the surplus measure, which is tantamount to treating construction as investment and not as consumption, thus makes sense from this standpoint too.

This operating surplus of states and localities is also shown in figure 1. In the 1950s state and local construction was much higher than the pension fund surpluses, so making the two exclusions raised the state and local operating surplus to nearly 2 percent of GNP. This surplus stayed at a high level through the late 1970s. It was still 1.8 percent of GNP in 1984. But since then, this series has dropped, down to 0.9 percent of GNP in 1990. Since 1974 the drop in state and local operating surpluses has accounted for a fifth of the drop in redefined national saving (with state and local construction treated as investment); since 1984 it has accounted for a third of the drop.

Although the two series describe the early years of the postwar period differently, the exclusions matter little after 1984. Whether one looks at the overall NIA surplus or, preferably, at the operating surplus, the drop has been sharp, dramatic, and a noticeable component of the decline in overall national saving. Since 1984 states and localities have clearly jumped on the national antisaving bandwagon.

There are at least three questions that arise in interpreting figure 1. A first question involves the current business cycle. Is the pattern of state and local fiscal behavior any different in the high unemployment year of 1991 (not in the figure) than in earlier high unemployment years? In terms of the cycle, the answer is basically no. Early indications for

3. To be precise, only net construction spending should be excluded, and some net investment components of nonconstruction spending should be excluded as well. There are no good estimates of either variable. The series presented is the closest simple approximation to an operating surplus. 
1991 are for another modest drop in the surplus-to-GNP ratio, which is consistent with earlier recessions. Also, special developments in federal grants contributed to the prerecession peaks in both 1972 and 1978 but did not occur this time. ${ }^{4}$

If there is a difference between this and previous epochs of high unemployment, it appears to be more a difference of trend than of cyclical pattern. The surplus seems to ratchet down to a lower level each cycle, so that the present recession started with the surplus already at a historic low. That, not the cyclical pattern itself, seems to be the main difference.

A second question is whether there is any special significance to zero. Does it matter that the operating surplus is now much closer to zero than it has ever been in the past four decades? In saving-investment terms there is clearly no particular significance to zero. A lower contribution to national saving is just that, whatever the level of the series. In government operation terms, there could be some significance, but the issue is trickier than commonly believed.

Unlike the federal government, virtually all states and localities operate under legal or constitutional budget constraints. These constraints are typically in stock terms, not flow terms. In other words, they usually do not prohibit state or local deficits; they only prohibit balances from falling below a certain level. A state or locality could run a deficit if it had previously saved enough to cover the deficit.

The fact that figure 1 is in flow terms when the true constraint works in stock terms makes it impossible to attribute particular significance to any target surplus, whether zero or any other number. So the fact that the surplus approaches zero does not necessarily mean anything. But since the ratio of the operating surplus to GNP has been falling recently, and has been at historically low levels for some time, the ratio of balances to GNP may be reaching historically low levels, perhaps dangerous ones.

Unfortunately it is harder to get consistent aggregate data on stocks than on flows. There is no series on balances strictly comparable to the NIA data, although the National Association of State Budget Officers (NASBO) does estimate general-fund balances for state governments.

4. The special circumstances of 1972 are described in Gramlich and Galper (1973); those of 1978, in Gramlich (1978). 
These are now only 2 percent of general-fund spending, the lowest that ratio has been since the start of the series. No comparable numbers exist for cities, but the National League of Cities has reported historically high deficits for $1991 .^{5}$ Together these data seem to confirm that both states and localities are in precarious financial circumstances.

A final question that could be asked about figure 1 is whether state and local fiscal problems have spread beyond their operating budgets. Here the news is better. The obvious place to look for evidence of spillover is in the market for the long-term bonds of municipal governments; these bonds finance capital construction. Changes in federal tax rates and treatments of bonds in the Tax Reform Act of 1986 affected the spread between private bond rates and tax-exempt municipal bond rates in the mid-1980s, but since 1988 the interest rate spreads between private bonds and comparably rated municipal bonds have been remarkably stable for all risk classifications. The stock of outstanding state and local capital debt is also at a normal ratio to GNP. For now, state and local operating budget problems apparently have not spread to the credit markets that finance capital investment.

\section{Spending, Taxes, and Grants}

Has the drop in the state and local operating surplus reflected a growth in government spending, tax cuts, or cuts in federal grants? Figure 2 shows current spending, taxes, and federal transfers, again in terms of annual data over the 1955-90 period as a percent of GNP. There is no question that the big news is the rise in spending, as Moore claimed. Current operating spending by state and local general governments (excluding pension funds and construction) grew from less than 6 percent of GNP in 1955 to 13 percent in 1990, with fairly steady growth in the 1980s. There have been periodic tax revolts at the state and local levels, and the reason for them is apparent too-state and local taxes rose from 6 percent of GNP in 1955 to 11 percent in 1990.

Another piece of news is that the path of federal grants, which has figured prominently in newspaper discussions of the state and local fiscal problem, has been rather uninteresting. Grants rose from 1 percent of GNP in 1955 to 3 percent by the mid-1970s and since then have tailed off

5. National Association of State Budget Officers (1991) and National League of Cities (1991). 
Figure 2. Receipts and Expenditures of State and Local Governments, 1955-90 Percent of GNP

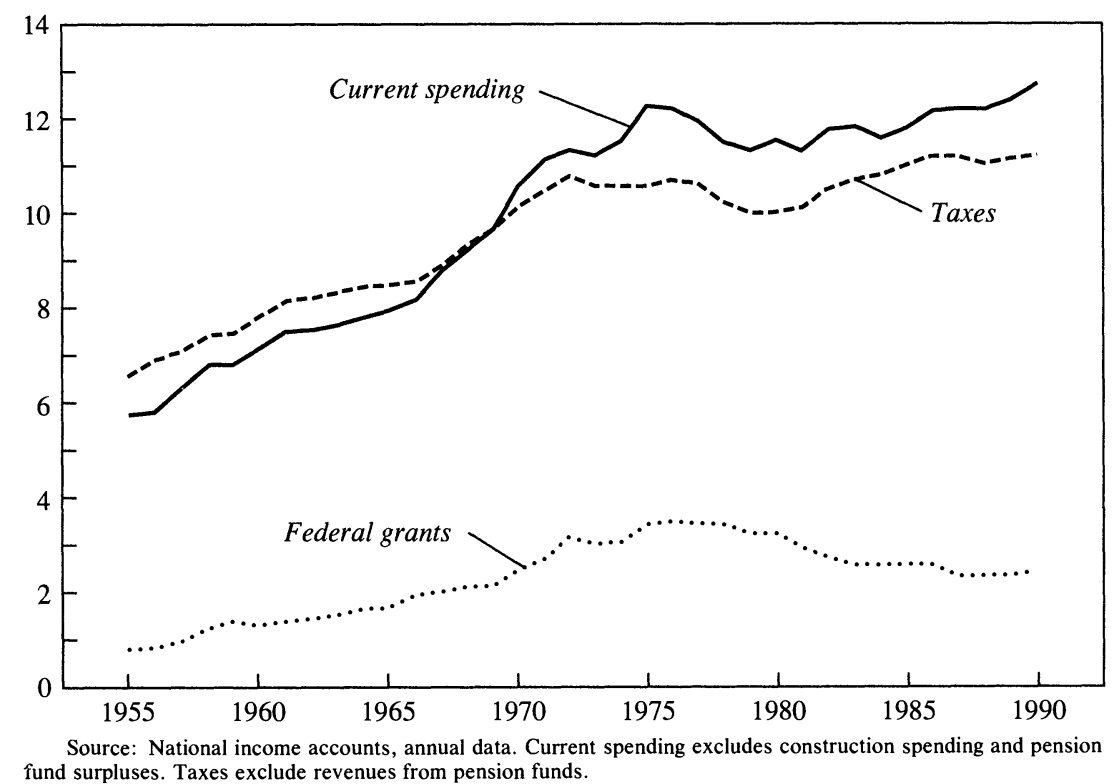

moderately. Federal general revenue sharing was cut out in two steps in the early and mid-1980s, accounting for about half of the drop in the share of grants; the remainder of the drop came about as part of the budget cuts in the early 1980s. Nevertheless, despite the dramatic claims of state and local officials, grants as a share of GNP have changed little since 1984 .

There are two senses in which federal grants might still have played a role in the drop in the surplus. One involves disaggregation. Federal grants for income support and medicaid are open-ended matching grants that probably lower the surplus in the short run; other federal grants are closed-ended nonmatching grants that probably raise the surplus in the short run. ${ }^{6}$ Back in 1984 income support grants were half of all federal grants; now they account for 60 percent. This compositional shift is of some importance in the empirical work described below.

There is another political sense in which the trend of grants might matter. Politicians get used to growth-in GNP (and thus in rising tax

6. This matter is explained in Gramlich and Galper (1973). 
Table 1. State Budget Variables, Selected Years, 1960-88

Percent of GNP

\begin{tabular}{ccccccc}
\hline & \multicolumn{2}{c}{ Revenue } & & \multicolumn{2}{c}{ Expenditure } & \\
\cline { 2 - 3 } Year & $\begin{array}{c}\text { Incoming } \\
\text { grants }\end{array}$ & Taxes & & $\begin{array}{c}\text { Current } \\
\text { spending }\end{array}$ & $\begin{array}{c}\text { Outgoing } \\
\text { grants }\end{array}$ & $\begin{array}{c}\text { Operating } \\
\text { surplus }\end{array}$ \\
\hline 1960 & 1.2 & 3.8 & 2.2 & 1.8 & 1.0 \\
1965 & 1.4 & 4.2 & & 2.4 & 2.2 & 1.0 \\
1970 & 2.0 & 5.2 & & 3.5 & 3.0 & 0.7 \\
1975 & 2.5 & 5.7 & & 4.4 & 3.2 & 0.6 \\
1980 & 2.4 & 5.8 & & 4.4 & 3.1 & 0.7 \\
1985 & 2.0 & 6.3 & & 4.7 & 2.9 & 0.6 \\
1988 & 2.0 & 6.3 & 4.9 & 3.0 & 0.3 \\
\hline
\end{tabular}

Sources: Levin and Peters (1986, 1987); Peters $(1988,1989)$.

revenues) and in grants. When growth slows, it may take politicians some time to get their budgets back on track. In this sense the slowing of GNP growth after 1973 and of grant growth after 1976 could still be subtly responsible for the rise in state and local deficits in the late 1980s. Yet state and local officials should surely have known that both GNP and federal grants were on lower growth trends, so it is hard to take this claim seriously.

\section{States and Localities}

The series so far have combined the accounts for states and localities. For some purposes, though, it may make more sense to disaggregate these accounts. Tables 1 and 2 do that for the 1960-88 period. ${ }^{7}$

One technical point should be noted about the tables. In the United States and virtually all other federal systems, the flow of intergovernmental grants is downhill-the federal government gives grants to states and localities, and states give grants to localities; grants do not flow in the other direction. There is a basic theoretical reason for this downhill flow. Because of factor mobility, the area over which taxes are assessed should be broader than the area over which benefits are dispersed, with downhill grants being a convenient (though not the only) means of eliminating the implied fiscal gaps. The upshot is that table 1, describing state

7. This limited time span is all that is available at present. The disaggregated data come in special supplements to the Survey of Current Business. See Levin and Peters (1986, $1987)$ and Peters $(1988,1989)$. 
Table 2. Local Budget Variables, Selected Years, 1960-88

Percent of GNP

\begin{tabular}{ccccc}
\hline \multicolumn{4}{c}{ Revenue } & \\
Year & $\begin{array}{c}\text { Incoming } \\
\text { grants }\end{array}$ & Taxes & $\begin{array}{c}\text { Current } \\
\text { spending }\end{array}$ & $\begin{array}{c}\text { Operating } \\
\text { surplus }\end{array}$ \\
\hline 1960 & 1.9 & 4.0 & 4.9 & 1.0 \\
1965 & 2.4 & 4.2 & 5.5 & 1.1 \\
1970 & 3.4 & 4.8 & 7.0 & 1.2 \\
1975 & 4.1 & 4.8 & 7.9 & 1.0 \\
1980 & 4.0 & 4.1 & 7.0 & 1.1 \\
1985 & 3.4 & 4.7 & 7.0 & 1.1 \\
1988 & 3.3 & 4.8 & 7.4 & 0.7 \\
\hline
\end{tabular}

Sources: Levin and Peters (1986, 1987); Peters (1988, 1989).

government budgets, has an entry for incoming grants (from the federal government) and for outgoing grants (to local governments), whereas table 2, describing local government budgets, has only an entry for incoming grants (from the federal and state governments).

In terms of the numbers, the growth in direct current spending has been evenly shared by state and local governments. Over the 1960-88 period the state share of direct current spending has risen 2.7 percentage points and the local share 2.5 percentage points. In addition, state outgoing grants have risen 1.2 percentage points, largely accounting for the fact that state taxes have risen more than local taxes. The recent surplus patterns have also been similar at both levels of government, with the surplus-to-GNP ratio dropping by 0.3 between 1985 and 1989 for states and by 0.4 for localities.

\section{Regions}

Another possibly meaningful disaggregation is by region. The fiscal problems in California, Massachusetts, New York, Connecticut, and Michigan are well known. Are things as bad everywhere?

Yes and no. The fiscal problems seem more serious in the states listed above than elsewhere. Yet more than 40 states now suffer fiscal problems. These budget problems are more easily analyzed for state governments because of the difficulty of surveying many thousands of local governments. To examine state budgets by region, I switch away from the NIA and focus on the self-reported accounts of state budget officers 
for fiscal years 1991 and 1992 as compiled by the National Conference of State Legislatures and the NASBO and as analyzed by Gold. ${ }^{8}$ Deficits are typically much larger in these data than in the NIA, in which there were still surpluses in 1990. As mentioned above, these new figures differ because they show projected deficits on a current services basis. Should states freeze their spending in nominal terms, these deficits will be reduced; should they postpone scheduled tax cuts, these deficits will be further reduced. Hence the self-reported budget projections are not good predictors of state budget deficits, though they do predict the adjustments necessary to bring state budgets into balance.

Table 3 shows the simple unweighted statewide regional averages of states' anticipated general-fund deficits. The averages are given as a percent of states' anticipated general-fund spending. For fiscal year 1991 these deficit ratios average 5 percent of spending across the country but almost 9 percent in New England and California. To simply eliminate the deficits would require budget cuts on the order of $\$ 35$ billion ( 0.6 percent of GNP), with some concentration in particular states but reductions in almost all of them.

Similar conclusions can be reached on the basis of the end-of-year balance estimates for fiscal year 1991, in the right column of the table. Assuming the deficits are not dealt with, balances would be negative in three areas, New England, the Mid-Atlantic states, and California. Because negative balances are not permitted, cuts of about $\$ 10$ billion would be the absolute least that could be done. And though other regions would escape the knife using this minimum standard, most of their balances would still be extremely low. Historically, state general-fund balances have averaged about 5 percent of general-fund spending, and, with no cuts, balances are projected to be below this level for states in all regions but the Great Plains and the Rocky Mountains.

Looking ahead to fiscal year 1992, problems become even worse. Now cuts of at least 5 percent of current spending are necessary in every region to balance budgets, with cuts of more than 20 percent necessary in New England and California. If the numbers are taken literally, budget cuts of close to $\$ 100$ billion ( 1.7 percent of GNP) would be necessary to bring state budgets into balance. There is no past epoch of budget cutting in the 35-year history shown in figure 1 that comes even close to this

8. National Association of State Budget Officers (1991) and Gold (1991). 
Table 3. Estimated Budget Deficits and Balances, by Region, Fiscal Years 1991 and 1992

Percent of general-fund spending

\begin{tabular}{|c|c|c|c|}
\hline \multirow[b]{2}{*}{ Region } & \multicolumn{2}{|c|}{ Deficit } & \multirow{2}{*}{$\begin{array}{c}\begin{array}{c}\text { General- } \\
\text { fund } \\
\text { balance }\end{array} \\
1991\end{array}$} \\
\hline & 1991 & 1992 & \\
\hline New England & 9.5 & 22.5 & -3.2 \\
\hline Mid-Atlantic & 5.6 & 12.6 & -0.3 \\
\hline Great Lakes & 5.1 & 5.6 & 2.6 \\
\hline Great Plains & 2.8 & 5.4 & 5.5 \\
\hline Southeast & 5.2 & 15.1 & 1.9 \\
\hline Southwest & 1.4 & 13.0 & 3.0 \\
\hline Rocky Mountain & 0.9 & $\ldots$ & 6.3 \\
\hline $\begin{array}{l}\text { Far West } \\
\text { (California only) }\end{array}$ & 8.6 & 33.0 & -1.3 \\
\hline
\end{tabular}

Sources: Gold (1991, table 1): National Association of State Budget Officers (1991). Estimates do not include data for every state in a region. The general-fund balance is a weighted average for the states in the region. The deficit is an unweighted average.

magnitude, which probably means that the numbers should not be taken so literally. But qualitatively the numbers do indicate that large budget problems lie ahead, that the problems get bigger the farther ahead one looks, and that while some states will feel the weight more heavily than others, fiscal problems are still quite general. If someone were planning to migrate away from fiscal problems, as is often assumed in public finance models, there would be nowhere to go.

\section{A Model of the Process}

I now try to isolate the effect of interral and exogenous factors on the budgets of state and local governments with the aid of a simple time series model. The model is fit to aggregate annual data over the 195590 period for state and local general governments combined. Because the disaggregated data cover a more limited period, building separate models for states and localities would have sacrificed four years of data on the front end of the time series and two years on the back end. Given the similarity of the state and local trends shown in tables 1 and 2, it did not seem sensible to bear this cost, so I used the longer aggregate time series. 
The model presented here is a modified version of a model I developed in an earlier paper. ${ }^{9}$ It assumes that state and local voters, or their elected representatives, gain positive utility from current government spending, private after-tax income, and the stock of balances. The latter stock represents power over either future spending or future private after-tax income. Utility is maximized subject to the budget identity:

$$
S=T+G-E,
$$

where $S$ is the state and local operating surplus, $T$ is taxes, $G$ is federal grants, and $E$ is current government expenditure. As in the preceding discussion, both construction and pension surpluses are excluded from the model, though as an empirical matter I will try to validate these assumptions.

Combining this budget identity with the identity that the surplus equals the change in asset balances yields the stock-flow identity, rewritten as

$$
B_{-1}+G=E-T+B,
$$

where $B_{-1}$ is the start-of-period stock of balances and $B$ is the end-ofperiod stock. In this equation, initial balances plus new grants can be allocated either to spending, to tax reduction, or to final balances according to the actions of state and local decisionmakers. The model does not explicitly deal with interest payments, even though they are becoming a major factor at the federal level and for particular state and local governments. For the whole state and local sector, however, interest is received on general-fund balances and paid out on construction bonds, with the result that net interest payments are still a tiny factor in state and local budgets, only 2 percent of total current spending. The model simply explains $E$ without separate detail involving interest and the balances.

Regression equations are estimated for $E,-T$, and $B$. Note that the tax equation is in a negative form. When this is done, the restrictions of the budget identity hold automatically if each independent variable (described below) is entered into each equation. Across the three equations the coefficients of $\left(B_{-1}+G\right)$ would then sum to one and the coefficients of all other independent variables would sum to zero. And since the coefficients of $\left(B_{-1}+G\right)$ sum to one, the coefficients of different compo-

9. Gramlich (1978). 
nents of $\left(B_{-1}+G\right)$ also sum to one, so that the constraining variable can be split apart to give different coefficients without violating the underlying budget identity.

Since one of the dependent variables is the stock of final balances, the model builds in a long-run stock adjustment behavior. In the short run, some exogenous variable will have a certain set of effects on $E,-T$, and $B$, with the coefficients summing to zero if this exogenous variable does not alter $\left(B_{-1}+G\right)$. But the change in $B$ in one period will then feed back into $B_{-1}$ in the next period to yield a new round of effects. In the long run, balances will be brought into equilibrium, which means that the change in balances, the surplus, is zero and the entire impact of the exogenous change is on spending and taxes.

The dependent variables are detrended by dividing by GNP, just as in the previous figures and tables. The independent budgetary variables (listed below) are also divided by GNP; the price deflators are divided by the GNP deflator. The independent variables are as follows.

-The initial stock of balances, with its coefficients summing to one across the three equations.

-Federal grants for income support and medicaid. Because these grants are a component of $\left(B_{-1}+G\right)$, the coefficients also sum to one across the three equations. As mentioned above, because these grants are open ended with relatively low federal matching rates, they would be expected to affect state and local budget items differently than other grants. ${ }^{10}$

-Other federal grants, also with coefficients summing to one across the three equations.

- The relative price deflator for state and local purchases, converted to percent by multiplying by 100 , with coefficients summing to zero across the three equations.

- The relative price deflator for health costs, also converted to percent and also with coefficients summing to zero across the three equations. The reason for including a health-cost deflator along with a purchases deflator is that health costs now impose a very large burden on

10. Income support grants really are endogenous and the model should have some correction for simultaneous-equations bias. But it is impossible to make a correction in a constraining variable (the coefficients of which should sum to one) without disturbing the constraints. Since the coefficients on income support grants were reasonable without any correction for simultaneity, I made no attempt to deal with this issue. 
the state and local transfer system. In 1989, for example, 11 percent of state and local operating expenses were for health-related costs actually paid to medical care providers and treated as transfer payments in the NIA. (With medicaid netted out, the share is still 5 percent.) This means that health costs will burden state and local budgets in a way not reflected by the purchases deflator. ${ }^{11}$

- The current and lagged unemployment rates, with coefficients for each summing to zero across the three equations. These variables reflect cyclical influences on both the spending and tax side.

To correct for serial correlation, all equations are converted to semidifferences with rho equal to 0.9 , though I also tried other values for rho to check for sensitivity. The residual statistics are in terms of these semidifferences (that is, for $e$ where $u=0.9 u_{-1}+e$ ). ${ }^{12}$

\section{Regression Results}

The regression results are shown in table 4. A $\$ 1$ increase in initial balances raises spending by $\$ 0.26$, raises taxes by $\$ 0.20$ - a clear wrong sign in the spirit of the model-and raises final balances by $\$ 0.95$. Thus, dollars that go into final balances only come out with long lags. Because of serial correlation in the balance series, this coefficient gets even closer to one when lower values of rho are tried.

With regard to grants, closed-ended grants, for everything other than income support and medicaid, raise spending by $\$ 0.36$ on the dollar, lower taxes by $\$ 0.28$, and raise balances by $\$ 0.36$. The short-run effect on spending is relatively modest because these grants are closed ended. As such, they do not change relative prices at the margin and act simply as new income for states and localities. But as the balances are converted to spending, the long-run effect on spending is greater.

There is a vast contrast between these effects and the effects of grants for income support and medicaid. The latter grants are open ended with federal matching shares that average 0.55 across all states. According to the coefficients, a $\$ 1$ increase in medicaid grants raises spending by

11. For this variable I use the health-care price in the consumer price index, deflated by the GNP deflator to put it in relative terms.

12. Because of the budget identity, the value of rho must be the same in all three equations. Fortunately, this restriction did not cause many problems-a large correction is necessary to remove autocorrelation in all three equations. 
Table 4. Regressions Explaining State and Local Operating Budgets, Annual Data, 1955-90

\begin{tabular}{|c|c|c|c|c|}
\hline \multirow[b]{2}{*}{ Independent variable } & \multicolumn{3}{|c|}{ Dependent variable } & \multirow{2}{*}{$\begin{array}{c}\text { Sum of } \\
\text { coefficients }\end{array}$} \\
\hline & Spending & Minus taxes & Balances & \\
\hline Constant & -9.304 & 2.853 & 6.452 & 0 \\
\hline Initial balances & $0.255^{*}$ & $-0.203^{*}$ & $0.949^{*}$ & 1 \\
\hline Income support and medicaid & $1.098^{*}$ & $-0.908^{*}$ & 0.810 & 1 \\
\hline Other grants & 0.360 & 0.279 & $0.361 *$ & 1 \\
\hline Purchases price & $0.102^{*}$ & $-0.080^{*}$ & $-0.023^{*}$ & 0 \\
\hline Health price & $0.824^{*}$ & -0.001 & -0.023 & 0 \\
\hline Unemployment rate & $0.111^{*}$ & 0.000 & $-0.111^{*}$ & 0 \\
\hline Lagged unemployment rate & 0.044 & $-0.060^{*}$ & 0.016 & 0 \\
\hline \multicolumn{5}{|l|}{ Summary statistic } \\
\hline$R^{2}$ & 0.890 & 0.619 & 0.901 & $\ldots$ \\
\hline Standard error & 0.128 & 0.147 & 0.151 & $\ldots$ \\
\hline Durbin-Watson & 1.641 & 1.349 & 1.648 & $\ldots$ \\
\hline
\end{tabular}

Source: Author's calculations. All budgetary variables as a percent of GNP; all other variables as percents. To correct for autocorrelation, semidifferences are estimated with rho equal to 0.9 . An asterisk denotes statistical significance.

$\$ 1.10$ (the grant plus another $\$ 0.10$ of matching), raises taxes by $\$ 0.91$, and raises balances by $\$ 0.81$. The spending coefficient accords with other information about the impact of these grants-that states and localities match the grants and then reduce other own-financed spending modestly. But the tax coefficient is again quite puzzling: why should taxes rise $\$ 0.91$ when there is only $\$ 0.10$ of own spending to finance? Apart from this incongruous detail, the broad pattern of the coefficients on federal grants is sensible. It is easy to see why governors complain about medicaid, which forces them to raise taxes, and lobby for other grants, which permit cuts in taxes.

The price terms serve as the main explanation for the upward trend in state and local spending relative to GNP. After solving the whole model, the coefficient on the purchases price variable implies that a 1 percentage point rise in prices raises the long-run money value of purchases by just about 1 percentage point, implying no long-run price elasticity of demand. For health-related transfers, a 1 percentage point rise in relative health prices raises both the short- and long-run money value of health-related transfers by more than 1 percentage point. There are other trends that could be influencing state and local spending growth, such as the growth in prison costs and the new growth in the number 
of school children, and there is always the risk that these trends, which cannot be easily estimated in an annual time series model, get mistakenly attributed to the price terms.

Finally, the unemployment rate serves as the cyclical variable. In the first year a 1 percentage point rise in the unemployment rate raises spending. States have some own-financed transfer payments that would rise automatically with a rise in unemployment, but the effect of unemployment on spending is larger than would be given by changes in these programs alone-there seems to be some discretionary increase in spending. ${ }^{13}$ There is no effect on taxes, and balances are lowered. On one hand, this reduction in balances feeds through to lower spending in future years; on the other hand, there is a new positive effect of lagged unemployment, this time financed mainly by tax increases. There is, then, a modest cyclical reaction in state and local budgets, with the surplus first dropping because of the spending increase and then recovering as taxes are increased. I discuss the normative implications of this pattern below.

Most of the coefficients reported in table 4 are more or less reasonable, except for the puzzling effects of the stock of balances and income support grants on taxes. Given the structure of the model, the results for balances are a particularly important defect because they imply that any time that a shock enriches (harms) state and local coffers, taxes will rise (fall). Hence before actually using the model, I reestimated the tax equation without initial balances and income support grants to eliminate these coefficients. The new coefficient estimates for the variables that remain are shown in table 5 and are much like those in table $4 .{ }^{14}$ The only change worth noting is that high unemployment now raises contemporaneous taxes, implying that some of the increase in cyclical spending is financed in the current year.

Two other modeling details deserve mention. One involves the

13. One piece of evidence supporting this claim comes from the fact that there is cyclical sensitivity in the spending of both states and localities, though only states have transfer programs that would seem to respond automatically to cyclical movements.

14. Reestimating the tax equation and not the spending equation means that the implied equation for balances is also changed. I never explicitly use the implied equation, only the equations for spending and taxes. To be sure, I also reestimated the whole system with a constraint technique that permitted the two variables to be dropped from the tax equation alone. The resulting estimates were similar to those of the spending equation in table 4 and the tax equation in table 5 . 
Table 5. Miscellaneous Budgetary Equations, Annual Data, 1955-90

\begin{tabular}{lccc}
\hline & \multicolumn{3}{c}{ Dependent variable } \\
\cline { 2 - 4 } \multicolumn{1}{c}{ Independent variable } & Minus taxes & $\begin{array}{c}\text { Pension } \\
\text { surplus }\end{array}$ & Construction \\
\hline Constant & -0.003 & -2.204 & 3.615 \\
Initial balances & $\ldots$ & 0.014 & 0.102 \\
Income support and medicaid & $\ldots$ & -0.094 & -0.006 \\
Other grants & 0.114 & -0.012 & 0.169 \\
Purchases price & $-0.097^{*}$ & $0.021^{*}$ & -0.037 \\
Health price & -0.004 & $0.008^{*}$ & -0.001 \\
Unemployment rate & $-0.075^{*}$ & $0.022^{*}$ & -0.009 \\
Lagged unemployment rate & $-0.044^{*}$ & 0.011 & $-0.066^{*}$ \\
Summary statistic & & & \\
$\quad R^{2}$ & 0.445 & 0.615 & 0.451 \\
Standard error & 0.171 & 0.040 & 0.115 \\
Durbin-Watson & 1.205 & 1.763 & 1.999 \\
\hline
\end{tabular}

Source: Author's calculations. See notes to table 4.

search for rho. A high value is plainly necessary to correct for serial correlation. As a procedural matter I tried several values before settling on 0.9. Most of the coefficient estimates are not very sensitive to rho values in this range, with the one exception being the speed-of-adjustment coefficient, which falls toward zero as rho is lowered. Hence lowering rho did not make much sense and raising it toward one gives the model the properties of a random walk, which is contrary to the equilibrium spirit of the underlying theory. Based on this logic, I chose 0.9 as the optimal value for rho.

Another detail concerns the exclusions. Throughout the paper I have argued that pension surpluses and construction should be kept out of the operating budgets for analytical purposes. That claim is generally accurate as a description of the way things should work in most jurisdictions, but it is possible that states and localities deal with fiscal crisis by passing up payments to their pension funds, through timely actuarial "reestimates" of required contributions to the pension funds or through cutting back on construction. The key question is how important these kinds of reactions are.

I tried to determine their importance by regressing both pension surplus as a percent of GNP and construction as a percent of GNP on the same set of independent variables, with the same correction for autocor- 
relation. The estimates are also shown in table 5. For the pension surplus, all of the fiscal variables are highly insignificant. The only variables that matter are unemployment and the price terms; the latter no doubt represent the strong upward trend in pension surpluses. But unemployment has the wrong sign, with a rise in unemployment actually raising state and local contributions to pension funds. It makes more sense simply to assume pension contributions are exogenous, as I have.

The matter is slightly less clear for construction. None of the fiscal variables are statistically significant, though the stock of previous balances is close and the coefficient has the expected sign. The trend terms and the current unemployment rate are statistically insignificant. Although the lagged unemployment rate is statistically significant, it too has the wrong sign, with a rise in unemployment lowering construction spending. Hence both the statistical criteria and the pattern of the coefficients give reasonable justification for treating construction as exogenous.

\section{Empirical Analysis of Post-1984 Drop}

I next use the spending coefficients in table 4 and the tax coefficients in table 5 to explain the post- 1984 decline in the operating surplus, previously noted on figure 1 . The results, which are quite good, are shown in figure 3 . The long series is the graph of the operating surplus from figure 1 , and the short series is a dynamic simulation of the model for the 198592 period.

When specified in levels, both the spending and tax equations fit almost perfectly in the most recent peak surplus year, 1984. I adjusted the constants slightly so that these two equations fit exactly in 1984 and then used that year as the starting point for a dynamic simulation for 1985-92. In this dynamic simulation, actual values of grants, prices, unemployment, and GNP were fed in; the equations then computed spending and taxes; and the identities given above computed the surplus and next period's balances. In turn, these balances were fed in with next period's exogenous variables to generate the next period's solution, with the process then repeated through 1992. For the 1991-92 calculations, budget forecasts were used for federal grants and the unemployment rate, and the price trends were extrapolated on the basis of recent data. 
Figure 3. Actual Operating Surplus, 1955-90, and Simulated Surplus, 1985-92

Percent of GNP

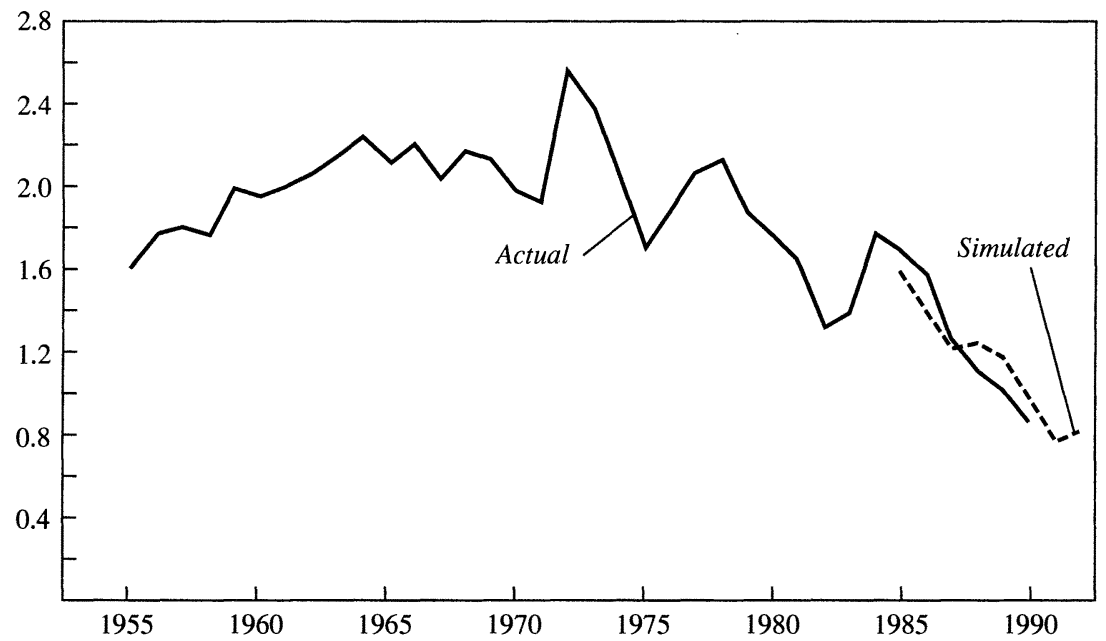

Source: National income accounts and author's calculations. The simulated surplus is calculated with the spending coefficients from table 4 , the tax coefficients from table 5, the actual values of independent variables from 1984 to 1990, and projections of the independent variables for 1991 and 1992.

The simulation generates a sharp drop in the surplus-to-GNP ratio, from 1.78 percent in 1984 to 0.78 percent at the trough in 1991 . The simulated value was not quite as low as the actual value in 1990 but did drop sharply in 1991 and will probably catch up with the actual value (which on early evidence is dropping modestly in 1991). Almost all of the residuals are in the spending equation, as the tax equation fits well throughout the whole simulation period.

As for what has caused the surplus drop, most discussion has centered on four possible factors. Probably the one most mentioned is cuts in federal grants. Changes in grant policy between 1984 and 1990, however, were only a modest contributor to the drop in the surplus-to-GNP ratio, about 0.16 percentage point of the total drop of 0.93 over that span. Little of this change was due to changes in income support grants. The coefficients above show that growth in income support grants has a modest surplus-reducing effect-they raise spending slightly more than they raise revenues. Hence while income support grants grew in the simulation period, their effect on the simulated surplus was slight. Most of the grant-based decrease was due to cuts in other federal grants. 
Another commonly discussed factor is the business cycle, represented by the unemployment rate in the model. It is immediately clear that changes in unemployment are not going to help explain the 1984-90 dive in the surplus because unemployment dropped by a full 2 percentage points between 1984 and 1990. Even the 1991 unemployment rate will almost certainly be lower than the 1984 rate. The drop in unemployment actually raised the surplus slightly.

A third possible factor in the drop in the surplus is the rise in state and local costs, particularly for health care. According to my estimates, this is far and away the most important factor contributing to the post-1984 decline. The coefficients above show that increases in the relative price of health care have a disproportionate effect on the surplus, generating a greater rise in current spending than if there were a simple proportionate rise in health-related transfer costs. Moreover, the relative price of health care has exploded since 1984 -it grew by an annual average of 1.3 percent over the three decades up to 1984 and by 3.7 percent a year since. (The reason for the explosion was partly in the denominatorhealth prices continued to trudge upward, while all other prices had slower growth.) This accounts for 0.49 point of the total drop in the surplus ratio of 0.93 point. Alternative calculations based on state and local own-financed health spending as a share of GNP yield estimates only two-thirds as large, so it is likely that these coefficients slightly overstate the role of health-care costs. ${ }^{15}$ Yet even these alternative calculations give health costs a greater role than any other variable, and it is possible there are indirect influences of health care throughout state and local budgets.

If these estimates are accurate, there are two important implications. First, the state and local fiscal problem is more a trend problem related to health-care costs than a cycle problem. Second, because of this, the state and local fiscal problems observed in 1991 are likely to get worse before they get better-that is, until health-care and related costs are

15. In 1984 own-financed health-care costs for states and localities were 1.8 percent of GNP; by 1989 they had grown to 2.0 percent of GNP. There was also a slight rise in the share of employee fringe benefits, probably largely the result of the rising relative cost of health insurance. Hence over this five-year period the change is about two-thirds of that given by the simulation. The National League of Cities (1991) also reports the rise in health-care costs to be the leading cause of city budget problems. 
controlled or there are alternative arrangements for paying these costs.

The fourth possible factor influencing state and local surpluses is federal mandates. These are not explicit in the model, but attempts by Timothy Conlan to quantify the annual costs of the mandates introduced since 1983 on state and local budgets (that is, net of any federal grants to pay a portion of these costs) yield estimates from $\$ 2$ billion to $\$ 5$ billion for 1990, accounting for a drop in the surplus-to-GNP ratio of less than 0.10 percent. ${ }^{16}$ At most, federal mandates seem a minor factor.

There are some other contributing factors that have played a smaller role in the drop in the surplus. Other variables in the model and all the dynamic factors led to some drop. The Tax Reform Act of 1986 has been alleged to be partially responsible, specifically because the act gave states a windfall (hence encouraging fiscal irresponsibility according to some) and eliminated the deductibility of sales taxes. A series of studies has shown that the windfall had little effect because it was roughly given back and that the deductibility provisions have so far had slight effects. ${ }^{17}$

Looking ahead, the dynamic simulation actually projects a slight turnaround (see figure 3). The simulated surplus continues to drop in 1991 , as the rise in unemployment adds to the trend effect of health costs. It then starts increasing in 1992 in response to the earlier rise in unemployment and the depletion of balances. This recovery is projected to be modest compared with the 1984-91 drop, a mere blip in what seems to be the steady downward trend of the state and local operating surplus. It is also modest compared with the required cuts in state budgets discussed earlier in connection with table 3 .

Hence the lesson of this simulation exercise is that the change in the surplus represents a fundamental worsening of the state and local budget position, most likely because of the growing importance of, and rapid explosion in, health-care costs and related influences, coupled with states' sluggishness in raising taxes to pay these health-care costs. There is a cycle in the surplus series, but it is small. Changes in grant policy added to the drop, but the effect was relatively minor and only in the

16. Conlan (1991).

17. See Ladd (1991) for the windfall and Courant and Gramlich (1990) for the tax treatment. 
composition of grants, not the level. Federal mandates played a minor role. Thus, the problem seems not to have been made in Washington or in state capitals but in the health-care sector, where costs have been rising dramatically.

\section{States and Localities over the Business Cycle}

The cyclical response of state and local budgets, though a relatively minor factor in the surplus story, has been discussed extensively, both in the public finance literature and in newspaper descriptions of the present fiscal problem. In this section I add briefly to the discussion.

There are three possible descriptions of how state and local budgets might behave over the business cycle:

-Neutrality. In this scenario, most clearly advocated by Wallace Oates but supported by almost any public finance or macroeconomics textbook today, state and local governments should not even attempt to conduct discretionary countercyclical policy. ${ }^{18}$ They should let their taxes and budget surpluses rise and fall automatically with changes in income. Their budgets would then be balanced over the business cycle but not year by year.

-Perversity. Rather than balancing budgets over the cycle, governments could balance year by year. Given the automatic movements of state and local taxes, this means that the discretionary fiscal policies of state and local governments would be perverse, with discretionary tax increases or spending cuts in recessions and tax reductions or spending increases in booms.

- Stability. Under this scenario state and local governments should do what most economists used to think the national government should do-that is, raise taxes or cut spending in booms and lower taxes or raise spending in recessions. Given that balances cannot become negative, such a strategy implies more asset accumulation in booms than would be suggested by neutrality (as well as more asset decumulation in recessions). But budgets would still be balanced over the business cycle, just as in the neutrality view. ${ }^{19}$

18. Oates (1972, chap. 1).

19. Hansen and Perloff (1944, chap. 10) made an old argument for such a strategy, but the only modern argument I know of is my own. See Gramlich (1987). 
On the descriptive side, the empirical model above indicates that actual policies have traces of all three elements. In the first year of a cyclical rise in unemployment, current spending rises, probably partly because of automatic increases in transfer payments and partly because of discretionary policy changes. The tax-to-GNP ratio rises slightly and the budget surplus falls.

This fall in balances then forces a perverse reaction. By the next year states are increasing taxes to pay for their higher spending and also cutting down on spending because of lower balances. In the long run, by the time all the lags have played out, a sustained rise in unemployment has slightly expansionary effects on both spending and taxes, with no effect on the surplus.

Given that there are traces of all three types of behavior-from stabilizing rises in spending to perverse rises in taxes-nobody can get too upset about the pattern from a normative standpoint. Nevertheless the consensus that has developed around the conventional neutrality view-that states and localities should not even attempt to conduct discretionary stabilization policy-can be faulted. According to this view, it is pointless for states to conduct countercyclical policy because their fiscal multipliers are small (goods are sold in a national market) and because states would be stuck with the debt occasioned by the fiscal change. Moreover, subnational fiscal policy is considered redundant because national monetary and fiscal policies can stabilize demand shocks.

If not wrong, several parts of this argument are now open to serious question. Subnational fiscal multipliers would indeed be small if all goods were sold in a national market, but the disproportionate growth of locally bought and sold services is changing things. National fiscal and monetary policies could stabilize demand shocks in all regions of the country if the shocks were highly correlated across the country. But many studies have shown that employment and output movements are not perfectly correlated across regions-upward movements or shocks in one state may be correlated with downward movements or shocks in other states..$^{20}$ Given these conditions, it may be impossible for national monetary or fiscal policy to stabilize demand conditions in all areas of the country simultaneously.

Whether states should try to fill the gap depends on the numbers. On

20. Summers (1986) and Barro and Sala-i-Martin (1991). 
the one hand, there are the usual problems with response lags, though the estimates above do indicate that somehow state and local spending rises more with current unemployment than with lagged unemployment. Any debt incurred in the future would remain and would impose future costs. On the other hand, the regional cycle will often persist, with the national government either unwilling or unable to do much about it on the monetary or fiscal side. In a world with a high degree of spending on nontradables, then, there may be some margin for subnational stabilization policy. ${ }^{21}$ In this sense, states and localities might usefully try limited doses of stabilization policy, and it would certainly be desirable for them to have accumulated enough assets in the good years that perverse policies could be avoided.

\section{Policy Changes?}

Cyclical issues aside, the dramatic drop in the state and local surplus since 1984 is harmful. From a state and local management point of view, the drop leaves states and localities with little defense against adverse shocks, given their already depleted balances. From a national saving point of view, the drop is one more blow to those who wish for higher national saving.

Are any policy changes in order? Since the driving force in the drop in the surplus seems related to the explosion in the relative cost of health care, that is the first place to look. When one does, two important problems become apparent:

-The rise in health-care costs themselves. These higher costs reflect the enormous and growing expense of the inefficient, inequitable, and patchwork system for financing health care in the United States. Until that is fixed, health-care costs will continue exerting a burden on living standards, the budgets of all governments, and national saving rates.

-The sharing of health-care costs. Whatever is done to control or not to control the public component of overall health-care costs, there is a good reason why the federal government, and not the states, should pay the major share of these costs.

21. The conditions are worked out in Gramlich (1987). 
It is going too far afield to analyze the health-care cost problem, and even the issue of which government should pay these costs. But there are arguments for bringing at least the state share of medicaid, about $\$ 30$ billion at today's rates, back to the federal level. First, were the federal government alone paying medicaid costs, it could more easily reform the system. Already that system is bedeviled by having too many uncoordinated providers of health insurance. ${ }^{22}$ Eliminating state governments from the patchwork system will not alone solve the problems of healthcost growth, but it is probably a necessary step. Second, since medicaid should be viewed as a form of income support for low-income groups, there are strong arguments for having the central government, not the states, pay these costs. Interstate inequities could be avoided if the federal government takes over low income-support programs, and interstate migration inefficiencies could be avoided. Also, for what it is worth, survey evidence indicates that most people feel income redistribution should be a national responsibility.

Moving health-related transfer costs to the federal government would go a long way toward solving the state and local fiscal problem. States and local budgets will always be susceptible to trend pressures, and state and local politicians will always be trying to spend more than they should or tax less than they should from a prudent fiscal point of view. Nonetheless, one large and growing load on state and local budgets would be lightened dramatically.

One immediate objection to having the federal government assume medicaid costs involves the federal deficit-how can the federal government assume more burdens when its deficit is already so high? Also, why does it help overall national saving just to shift an expense from one government to another? The discussion above gives two answers: social efficiency would be served by having the federal government take over medicaid, and the switch would make it easier to control the cost of health care.

The immediate effect of the switch on government budgets could be neutralized by making the switch revenue neutral. There are many ways of making revenue-neutral changes, most of which also serve social efficiency. Many federal grants now have federal matching shares much 
higher than could be justified on the basis of interjurisdictional spillovers, and these matching shares could be altered with a gain in social efficiency. The justification for the federal income-tax deduction of state and local taxes is tenuous; it could be eliminated with a gain in both efficiency and equity. ${ }^{23}$

Short of these types of changes, other measures seem like needless tinkering. It makes little sense to raise other federal grants for fiscal reasons alone-by definition, there would be no social justification for the grants, nothing would be done about the health-care finance problem, and the grants would probably not go to those states getting hurt by growing costs. It makes little sense to institute new fiscal loans for states-such loans could address cyclical problems but not trend problems. ${ }^{24}$ It makes little sense to tamper with the fiscal restrictions now constricting state and local fiscal behavior-these are already flexible, permitting saving in good years and dissaving in bad years; and one cannot see how they could be improved, from either a public finance or a macroeconomic point of view.

\section{Conclusion}

The 1991 state and local fiscal crisis, or rather the drop in state and local saving, actually began in 1984, a few years after the cuts in federal grants by the Reagan administration, and continued through a prolonged economic expansion. Estimates of the effect of both grants and unemployment on the surplus give modest results not always in the right direction. The main cause of declining state and local surpluses is found not in the behavior of either one of these commonly mentioned factors but in the large effects and explosive growth of health costs and related influences on the transfer systems of state and local governments.

Given this source of difficulty, there is both good and bad news. The good news is that the remedy seems clear. The most promising change is for the federal government to take over the financing of health-care

23. These matters are discussed in Gramlich (1985).

24. It should also be noted that states already have two mechanisms for cyclical smoothing. Many states have rainy day funds that permit saving in good years and dissaving in bad years. If this is not enough, they can also borrow from their unemployment trust fund. See Burtless and Vroman (1984). 
costs, making the change revenue neutral if need be. Until that is done, and the federal government then uses its leverage to control health-care costs, no other policy looks to have any lasting value. The bad news is that it will not be easy to make such a change or to control these costs. Another piece of bad news is that if measures like this are not undertaken, state and local budgets are likely to continue under severe and growing fiscal pressures. 


\section{Comments and Discussion}

Robert J. Gordon: Journalists have written extensively on the state and local fiscal crisis and have attributed it in roughly equal proportions to the reversal by the Reagan administration of Nixon's "New Federalism" and to the overly generous compensation of state and local government employees, in turn the result of cowardly politicians bowing to pressure from civil service unions. ${ }^{1}$ In this journalistic view, the problem originates both in Washington and in the centers of state and local government. Ned Gramlich's paper dismisses the role of Washington as minor and fails to discuss the issue of relative compensation, pointing instead to an exogenous shift in the relative price of medical care as the most important single cause of the crisis. In my view, medical care is not a separate problem that dropped from the sky, but is just one part of the general indictment of the federal government on its mismanagement of the economy. And the data suggest that the journalistic attention to relative compensation levels in state and local government is warranted if we look only at the past decade, but is less convincing over a broader historical perspective.

\section{Defining the Surplus}

The author's paper raises an interesting issue at its beginning, the proper definition of the state and local surplus. The discussion, how-

1. A concise history of the reversal of the "New Federalism" is contained in Thomas R. Swartz and John E. Peck, "The Changing Face of Fiscal Federalism," Challenge, November-December 1990, pp. 41-46. For discussions of the increase in state and local compensation per hour relative to private sector compensation, see Andrew Bates, "Blame Game: The Great State Budget Hoax," New Republic, November 4, 1991, pp. 11-12, and Gene Koretz, "Fat Paychecks Got States and Cities Deep in Hock . . .," Business Week, September 23, 1991, p. 26. 
ever, is confusing, because it jumps back and forth between two quite different issues: the effect of state and local government on national saving and the proper measure of fiscal pressure for state and local decisionmaking. Clearly, a decision about the correct measure is crucial to any reference to a "crisis," since in figure 1 the secular deterioration comes only in the operating surplus measure; the NIA measure shows the state and local sector to be much better off now than in the 1950s and 1960s.

To clarify the issues, one can take the standard national-accounts identity and break out the two items that distinguish the state and local operating surplus from the NIA measure of the surplus-government investment and the surplus on retirement funds. The standard identity is

$$
I_{p} \equiv S_{p}+(T-E)-X,
$$

where the $p$ subscript denotes private, and the terms are investment $(I)$, saving $(S)$, tax revenue $(T)$, government expenditures $(E)$, and net exports $(X)$. We can divide up $E$ into the components relevant to Gramlich's definition:

$$
E \equiv I_{g}+C_{g}+F_{g}-S_{r g}
$$

where the $g$ subscript denotes government, and the new terms are consumption $(C)$, transfers $(F)$, and the excess of contributions to government pensions over the benefits paid out $\left(S_{r g}\right)$. The spending item $S_{r g}$ (that could alternatively be treated as part of revenue) is what the NIA calls the "surplus on social insurance funds," which for the federal government is the social security surplus and for state and local government is mainly the surplus of state and local government retirement funds (or the "pension surplus").

The NIA measure of the surplus $(N)$ of both federal and state and local government is simply

$$
N \equiv T-E,
$$

where grants-in-aid are included in the federal component of $E$ and the state and local component of $T$. Gramlich's "operating surplus" $(O)$ is

$$
O \equiv N+I_{g}-S_{r g} \equiv T-F_{g}-C_{g} .
$$

The operating surplus leads to a rearrangement of the original NIA identity that puts all investment on the left and divides up the sources of 
finance into private saving, government pension saving, the operating surplus, and foreign borrowing.

$$
I_{p}+I_{g} \equiv S_{p}+S_{r g}+O-X,
$$

that is, $O$ is the contribution of the government, net of the government pension surplus, to saving available to finance total investment (private and government).

Now, should one follow Gramlich and use $O$ as a measure of government saving in examining the financing of investment and economic growth? I think not. Although it makes sense to add back government investment, it makes no sense to subtract the pension surplus. Consider a situation in which every term in equation 5 is a constant, expressed as a percentage of GNP, except for $O$ and $S_{r g}$. Assume that $S_{r g}$ goes up by 1 percentage point of GNP, while $O$ goes down by the same amount. The sum of the right-hand side of equation 5 is constant, and the nation has the same ability to finance total investment. Yet Gramlich will contend there is a crisis because $O$ has declined by 1 percent of GNP, just as it did between 1984 and 1990.

Putting this another way, the secular decline in Gramlich's measure of the operating surplus mixes up two effects, the decline in $I_{g}$, which is bad, and the increase in $S_{r g}$, which cancels the decline in $O$ and on balance indicates a zero effect of the government sector on national saving. The true impact of the government on the financing of total investment is captured by the alternative operating surplus variable, $O^{*}$, where $O^{*} \equiv N+I_{g} \equiv O+S_{r g}$; thus,

$$
I_{p}+I_{g} \equiv S_{p}+O^{*}-X .
$$

As I will show below, the alternative $O^{*}$ measure has declined over the $1970-90$ period by less than half as much as Gramlich's $O$, implying that the "crisis" is much less severe than he asserts.

The second purpose of an alternative surplus variable is to capture fiscal pressure that allows one to predict when the shouts of crisis will be heard in state capitals and city halls across the land. Here Gramlich's argument is that government investment can be financed by borrowing and thus should be taken out of expenditure, whereas the pension surplus is outside the control of decisionmakers. The first problem is that government capital is clearly not all financed by borrowing. If it were, in a steady state, interest payments would be equal to government invest- 
ment. But the record shows that until the past few years government interest payments were less than half of construction expenditure, and, in turn, construction expenditure (used by Gramlich as an approximation for $I_{g}$ ) understates total state and local government investment, which also includes spending on durable goods. There is also a question about the pension funds; I suspect that at least some state and local government units can count at least part of their pension fund surplus toward the constitutionally mandated minimum constraint on its operating balances.

\section{Another Look at the Numbers}

Table 1 attaches numbers to these symbols in order to determine whether expenditures or revenues are the culprit, whether the crisis is homegrown or Washington-grown, and whether excessive increases in the compensation of state and local government employees have played a role. The numbers are cyclically corrected by displaying years when actual real GNP was roughly equal to natural real GNP. Hence I compare four years of similar cyclical conditions. Table 1 leads to different conclusions and points of emphasis than Gramlich's analysis.

First, in contrast to Gramlich, who puts much of the emphasis on rising expenditures, I find that the expenditure share hardly increased from 1970 to 1987: increases in transfers and "other" expenditures (government consumption) were almost exactly offset by a drop in construction and an increase in interest income, treated as negative expenditure in the NIA. Only since 1987 has growth in expenditures emerged, being about equally divided between transfers and consumption. (Of the 0.63 percentage point increase in expenditures during the 1987-90 period, only a third, $\mathbf{0 . 2 2}$, is due to medical care expenditure.) Since taxes went up and by 1987 grants-in-aid had returned to roughly their 1970 level, the NIA surplus increased by almost a full percentage point between 1970 and 1987 and then lost about half of this gain between 1987 and 1990.

Second, the decline in Gramlich's operating surplus $(O)$ from 1970 to 1990 was 1.11 percentage points; using the alternative $O^{*}$, which leaves in the pension surplus, the decline becomes 0.52 points. Thus for the debate over national saving, I find that during the $1970-90$ period the state and local sector subtracted about 1 percentage point from total in- 
Table 1. Interesting Facts about State and Local Government, Selected Years, 1970-90 Percent of GNP, unless otherwise noted

\begin{tabular}{|c|c|c|c|c|}
\hline Item & 1970 & 1979 & 1987 & 1990 \\
\hline Revenues & 13.37 & 14.17 & 14.51 & 14.65 \\
\hline Taxes & 10.97 & 10.96 & 12.24 & 12.24 \\
\hline Grants-in-aid & 2.40 & 3.21 & 2.27 & 2.40 \\
\hline Expenditures & 13.20 & 13.07 & 13.38 & 14.00 \\
\hline Transfers & 1.98 & 2.28 & 2.65 & 2.98 \\
\hline Construction & 2.47 & 1.71 & 1.44 & 1.47 \\
\hline Net interest & -0.18 & -0.47 & -0.77 & -0.76 \\
\hline Other & 8.92 & 9.54 & 10.06 & 10.31 \\
\hline NIA surplus & 0.18 & 1.10 & 1.13 & 0.65 \\
\hline Social insurance & 0.68 & 0.95 & 1.31 & 1.27 \\
\hline Other & -0.50 & 0.15 & -0.18 & -0.62 \\
\hline \multicolumn{5}{|l|}{ Operating surplus ${ }^{\mathrm{a}}$} \\
\hline Gramlich $(O)$ & 1.97 & 1.87 & 1.26 & 0.85 \\
\hline Alternate $\left(O^{*}\right)$ & 2.65 & 2.81 & 2.57 & 2.12 \\
\hline \multicolumn{5}{|l|}{ Addenda } \\
\hline Grants less transfers & 0.42 & 0.93 & -0.38 & -0.58 \\
\hline Residual $^{\mathrm{b}}$ & -0.93 & -0.78 & 0.20 & -0.05 \\
\hline $\begin{array}{l}\text { Medical care } \\
\text { transfers }\end{array}$ & 0.53 & 0.86 & 1.10 & 1.32 \\
\hline \multicolumn{5}{|c|}{$\begin{array}{l}\text { State and local sector } \\
\text { relative to total economy }(1987=100)\end{array}$} \\
\hline Employment $^{\mathfrak{c}}$ & 97.0 & 103.0 & 100.0 & 100.6 \\
\hline Deflator $^{d}$ & 89.2 & 94.4 & 100.0 & 102.6 \\
\hline $\begin{array}{l}\text { Compensation per } \\
\text { employee }^{\mathrm{e}}\end{array}$ & 98.1 & 94.0 & 100.0 & 102.7 \\
\hline
\end{tabular}

Sources: National income accounts and Economic Report of the President 1991.

a. Gramlich's operating surplus $(O)$ is the sum of the NIA surplus excluding social insurance funds (labeled "other") and construction expenditures. My alternative measure $\left(O^{*}\right)$ is the sum of the total NIA surplus and construction expenditures.

b. The residual is the "other" NIA surplus minus "grants-in-aid less transfers." It measures the net surplus of the rest of state and local budgets.

c. For 1970-87, relative employment is state and local government employment (NIA table 6.10B, line 82) divided by the total number of production employees (same table, line 1). These numbers are linked to the 1989-90 figures in Economic Report of the President 1991 (table B-43) to determine the 1990 figure.

d. The deflator is the state and local government deflator (NIA table 7.4, line 20) relative to the GNP deflator (same table, line 1).

e. For $1970-89$, relative compensation is compensation of state and local employees (NIA table 6.4B, line 82) relative to total compensation. The series is linked to the 1989-90 state and local compensation (NIA table 3.7B) relative to total compensation (NIA table 1.14) to determine the 1990 figure. The index of compensation per employee is the resulting index for relative compensation divided by the index of relative employment.

vestment but added about a half point back through its pension surplus, which was available to finance private investment. On balance, the state and local sector contributed a net subtraction of one-half a percentage point to the funds available to finance total (private plus government) investment. 
Third, and perhaps most important, the table shows the tremendous whiplash of grants-in-aid minus transfers over the period, which dramatizes my conclusion that the crisis was made in Washington. Grants-inaid minus transfers shifted from 0.93 percent to -0.58 percent of GNP during the 1979-90 interval-a turnaround of 1.5 percent of GNP-as Washington simultaneously slashed its grants to the state and local sector while mandating extra transfers. Of the 1.5 percentage points, less than one-third, or 0.46 percentage point, was due to medical care transfers. The process began in the last two Carter budgets but can mainly be laid at the door of Reagan's decision to reverse Nixon's "New Federalism." The residual in the table is the net surplus of the rest of the state and local budget, showing that between 1979 and 1990 revenues were raised by only about half the amount needed to reverse the whiplash.

Finally, what about the claims of journalists who point to the excessive rise in state and local compensation per employee? The bottom section of table 1 provides indexes on the relative share of state and local employment in the total economy, the relative deflator, and relative compensation per employee. Between 1979 and 1990 the increase in the relative deflator corresponds almost exactly to the increase in relative compensation, vindicating the journalists and shifting some of the blame for the crisis to state capitals and city halls. But the journalists have not noticed that the relationship does not hold before 1979; the relative deflator and relative compensation went in opposite directions between 1970 and 1979, suggesting that some of the behavior of compensation in the 1980s was a "catch-up" phenomenon. ${ }^{2}$ Thus any aggressiveness of state and local unions or passivity of politicians is a relatively recent phenomenon that needs to be acknowledged and explained, but it does not extend before 1979 .

\section{A Broader Interpretation}

What should we make of all this at the deeper level of political behavior? Despite all the stories about profligate state and local governments,

2. Going back even further, the 1960 index numbers for the relative deflator and relative compensation per employee are 77.8 and 94.9 respectively, confirming the view that until 1979 the increase in the relative deflator cannot be attributed to relative compensation and that after 1979 it can. 
in the past two decades employment, state and local consumption spending, and compensation per employee have been amazingly constant as a share of the national economy. State and local governments have increased transfer spending by 1 percentage point of GNP, and most of this increase $(0.79)$ has consisted of medical care transfers. These rising transfers have been almost exactly offset by a drop in construction, and this shift may have been sensible in view of the fact that building the interstate highway system is a one-shot deal and slower population growth required fewer new schools. Rising net interest receipts until recently were able to finance most of the increase in consumption.

In addition to the increase in relative compensation per employee in the 1980s (much of which may have been a catch-up from the 1970s), the other main area of blame for state and local governments can be attributed to self-imposed shifts in the structure of the state and local tax systems. By one estimate, the elasticity to personal income of state and local tax revenues fell from 1.6 to 1.25 over the 1980 s, as a result of indexing, caps on property tax increases, and a shift of income to states with no income tax or relatively flat tax structures. ${ }^{3}$

But, leaving aside the issues of compensation and tax structure, the basic problem comes down to a failure of the state and local governments in the 1980s to raise tax revenues in the full amount needed to compensate for Scrooge in Washington. This shortfall is trivial compared with the more important failure of Scrooge to finance its own transfer payments. Between 1970 and 1990 the increase in the share of federal government spending in GNP (2.9 percentage points) corresponded almost exactly to the increase in the share of federal government transfer payments (3.1 points), and only one-third of this was financed by increased federal revenues ( 1.1 points). From this perspective the state and local fiscal crisis is a mere sideshow to the failure of political will in Washington, where for years reductions in tax rates for the wealthiest 20 percent of the income distribution were introduced under the smokescreen of "incentives to growth," while successive administrations and Congresses refused to consider paying the bill for the transfer payments that they had mandated at both the federal and state

3. Vivian Brownstein, "Why State Budgets Are a Mess," Fortune, June 3, 1991, pp. 21-30. 
and local level. Only a part of this overall phenomenon, perhaps a third, can be attributed to the rising relative price of medical care. It is beyond the scope of Gramlich's paper and my comments here to examine medical care systems in Canada or other countries to determine how much of this relative price phenomenon is a by-product of the inefficient nonsystem of medical care in the United States.

Just as the problem has been created in Washington, it can be fixed in Washington by reversing the policies of the past decade. This would be a much more direct approach than federal fiscal loans to states, which Gramlich discusses at the end of his paper, using the somewhat bogus argument that the federal government is farsighted whereas state and local governments are myopic. Even taken on its own merits, this proposal is subject to the fatal flaw that it requires the lender to be able to distinguish demand shocks from supply shocks as causes of fiscal problems in particular states. Texans lived like sheikhs when oil prices were high, and individual Texans borrowed up to their teeth to develop projects that soon went sour; then the wheeler-dealers marched en masse into bankruptcy. The only solution for the Texas state government was to accept a lower permanent income, and any loan from Washington would have only postponed the adjustment. The loan scheme only makes sense if it is certain that the problem is a temporary demand shock and that there will be good years in the future during which the loans can be repaid.

\section{The Real Problem}

To conclude, let me focus on the real problem. Federalism is a curse, as is the absence in most American cities of full-fledged Toronto-style metropolitan government. The issue at the local level is income inequality and the need to equalize spending on basic public services between central cities and suburbs. Inequality across states is not nearly as great as within states, making the basic argument against federalism the classic point that is well stated in Gramlich's paper-there should be a downhill flow of government grants because of factor mobility, and taxes should be assessed over a wider area than the span of spending benefits.

America has a big productivity problem, and I recently discovered a 
new way of dramatizing this. Among the Group of Seven nations the United States is the only one in which productivity growth since 1973 has been significantly below the average over the century preceding 1973. For the other six nations the past two decades score well above the previous century. While retaining a role for local government in the framework of metropolitan-wide jurisdictions, there would be no greater beginning toward a productivity recovery than to close down all statehouses and state legislatures and divert the energies of thousands of well-educated lawyers, lobbyists, and legislators toward productive activity in the private sector rather than continue to waste their talents on duplicative activity in the 50 state capitols.

\section{General Discussion}

Alice Rivlin remarked on a broad parallel between the decline of state and local operating surpluses after 1984 and the unusual pattern of income distribution documented in the paper by David Cutler and Lawrence Katz in this volume. She suggested the latter might help explain the former. In the 1980 s, poverty and near poverty did not improve as they had in earlier economic expansions, forcing poverty-related spending to stay high. At the same time, real revenue growth was held down by the fact that real incomes grew rapidly only for the highest-income individuals, who are taxed relatively lightly by states and localities. James Poterba added that for taxpayers who itemize deductions the sales tax has become a more expensive way of financing states' expenditures because the 1986 tax reform eliminated the deductibility of state sales tax against federal tax liabilities. If this change influenced the median voter, it might have made it more difficult for states to raise revenue. Gramlich noted that, paradoxically, states' reliance on sales taxes has increased rather than decreased since the Tax Reform Act of 1986. Benjamin Friedman speculated that the recent unwillingness of state and local governments to raise taxes, or even to sustain current tax levels, may reflect dated thinking from the early days of the tax revolt. When Proposition 13 was passed in California, the state had a very large operating surplus. At that time, and in other states in subsequent years, revenue growth could be limited without reducing spending. By the late 1980 s, when spending needs required more revenues, taxpayer resis- 
tance based on the earlier experience continued to make it difficult to raise them.

Robert Barro agreed with Gramlich's treatment of state and local pension surpluses as part of private saving rather than as part of the government surplus; he suggested that the reasoning should be extended to social security and government budget surpluses more generally. Although granting that individuals might have better-defined property rights in state and local pension funds than they do in social security or in government net worth, he nonetheless regarded any division between public and private components of saving as fundamentally arbitrary and not very informative.

Olivier Blanchard suggested that increases in the state expenditure deflator may stem more from the behavior of the states than from changes in the costs they face. He noted that the state expenditure deflator consists primarily of wages and that states have considerable control over the rate of this wage growth. Lawrence Katz added that although state and local government wages rose at about the same rate as private sector wages over the past decade, state and local compensation rose noticeably faster because of rapid increases in pension plans and other fringe benefits. He also noted that real wages of state and local government employees, many of whom are relatively less educated, changed little in the 1980s, while real wages for less educated workers in the private sector dropped by about 20 percent. 


\section{References}

Aaron, Henry J. 1991. Serious and Unstable Condition: Financing America's Health Care. Washington: Brookings.

Barro, Robert J., and Xavier Sala-i-Martin. 1991. "Convergence across States and Regions." BPEA, 1:1991, 107-58.

Burtless, Gary, and Wayne Vroman. 1984. "The Performance of Unemployment Insurance since 1979." Industrial Relations Research Association Series, Proceedings of the Thirty-Seventh Annual Meeting, 138-46.

Conlan, Timothy. 1991. " A Decade of Change in Regulatory Federalism: Evaluating Regulatory Trends and Relief Strategies for the 1990s." Unpublished paper. Washington: Advisory Commission on Intergovernmental Relations.

Courant, Paul N., and Edward M. Gramlich. 1990. "The Impact of TRA on State and Local Fiscal Behavior.' In Do Taxes Matter? The Impact of the Tax Reform Act of 1986, edited by Joel Slemrod. Cambridge: MIT Press.

Gold, Steven D. 1991. "Will Elimination of State Government Deficits Be a Big Drag on the Economic Recovery?' Unpublished paper, State University of New York, Albany (June).

Gramlich, Edward M. 1978. "State and Local Budgets the Day after It Rained: Why Is the Surplus So High?' BPEA, 1:1978, 191-214.

- 1985. "Reforming U.S. Fiscal Federalism Arrangements." In American Domestic Priorities: An Economic Appraisal, edited by John M. Quigley and Daniel L. Rubinfeld. Berkeley: University of California Press.

- 1987. "Subnational Fiscal Policy.' In Perspectives on Local Public Finance and Public Policy, vol. 3, edited by John M. Quigley.

Gramlich, Edward M., and Harvey Galper. 1973. "State and Local Fiscal Behavior and Federal Grant Policy." BPEA, 1:1973, 15-58.

Hansen, Alvin Harrey, and Harvey S. Perloff. 1944. State and Local Finance in the National Economy. New York: W.W. Norton and Company.

Ladd, Helen F. 1991. "State Responses to the TRA86 Revenue Windfalls." Unpublished paper, Duke University (July).

Levin, David J., and Donald L. Peters. 1986. "Receipts and Expenditures of State and Local Governments: Revised and Updated Estimates, 1959-84." Survey of Current Business 66(May): 26-33.

- 1987. "Receipts and Expenditures of State Governments and of Local Governments: Revised and Updated Estimates, 1983-86." Survey of Current Business 67(November): 29-35.

Moore, Stephen. 1991. " State Spending Splurge: The Real Story behind the Fiscal Crisis in State Government."' Policy Analysis 152. Washington: The Cato Institute (May).

National Association of State Budget Officers. 1991. Fiscal Survey of the States: March 1991. Washington: National Governors' Association. 
National League of Cities. 1991. "Special Report: City Fiscal Conditions, 1991.' In Nation's Cities Weekly, July 8.

Oates, Wallace E. 1972. Fiscal Federalism. New York: Harcourt Brace Jovanovich.

Peters, Donald L. 1988. "Receipts and Expenditures of State Governments and of Local Governments: Revised and Updated Estimates, 1984-87.' Survey of Current Business 68(September): 23-25.

- 1989. "Receipts and Expenditures of State Governments and of Local Governments: Revised and Updated Estimates, 1985-88.' Survey of Current Business 69(October): 24-27.

Summers, Lawrence H. 1986. "Why Is the Unemployment Rate So Very High near Full Employment?”' BPEA, 2:1986, 339-83. 